\title{
Fluoride release from conventional, resin-modified and hybrid glass ionomer cements
}

\author{
Maja Ležaja Zebić, Nikola Jakovljević, Vesna Miletić \\ University of Belgrade, School of Dental Medicine, Department of Restorative Odontology and Endodontics, Belgrade, \\ Serbia
}

\begin{abstract}
SUMMARY
Introduction The aim of the study was to quantify and compare fluoride release from four different glass ionomer cement products (GICs).

Materials and Methods Standardized disk-shaped samples ( $5 \times 2 \mathrm{~mm} ; \mathrm{n}=5 /$ group) of GIC restorative materials: conventional (Fuji IX, GC Corp., Japan), resin-modified (Fuji II LC, GC) and hybrid glass ionomer cement (Equia Forte, GC) and a conventional GIC liner/base material (Alfagal, Galenika, Serbia) were tested for fluoride release up to 21 days postsetting. Each sample was immersed in $5 \mathrm{~mL}$ of fresh deionized water during each time interval. Universal microhybrid composite (Filtek Z250, 3M EPSE, USA) and adhesive (Adper Single Bond, 3M ESPE) were used as negative controls. Fluoride release was measured using an F-selective electrode (Cole-Parmer, USA) and an ion meter (Oakton 700, Cole-Parmer, USA). Data were statistically analyzed using one-way ANOVA, regression and correlation analysis at 0.05 . Results The highest total fluoride release was measured from Alfagal (386 $\pm 61 \mathrm{ppm} / \mathrm{g})$, and significantly less from

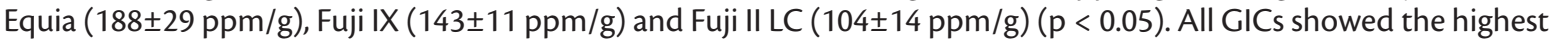
fluoride release during the first 24 hours post-setting. After 3 days, fluoride release slowed down reaching a plateau for all materials. Regression and Pearson correlation analysis showed significant inverse relationship between fluoride release and sample mass and density $(p<0.001)$.

Conclusion Of the three GICs indicated for use as restorative materials, Equia Forte released the highest fluoride concentration. Fluoride release was material and density dependent, with higher release occurring from lower density GICs. Keywords: fluoride; glass ionomer cements; glass hybrid; resin-modified glass ionomer
\end{abstract}

\section{INTRODUCTION}

One of the main reasons for restoration failure is secondary caries $[1,2,3]$ which results in further tooth tissue loss, weakened remaining tooth structure or even premature tooth loss. Any mechanism that inhibits acid production by bacteria, increases resistance to demineralization or facilitates remineralization could be considered clinically significant. A recent study showed that the most commonly used restorative materials in contemporary restorative dentistry, resin-based composites, do not exhibit buffering potential, thus being more susceptible to the formation of secondary caries around such restorations [4].

Fluoride from fluoride-containing materials has the capacity to chemically interact with hydroxyapatite of enamel and dentin adjacent to the restoration resulting in the formation of fluorapatite $[5,6]$ which increases resistance to acid demineralization and prevents secondary caries $[7,8]$. Fluoride released from fluoride-containing restorative materials, such as glass ionomer cements (GICs), may improve resistance to demineralization $[9,10]$, facilitate remineralization $[11,12]$ or even directly affect cariogenic bacteria by inhibiting their metabolic enzymes [13]. Fluoride was found in dentin, released from the bottom parts of GIC restorations (Fuji IX and Fuji II LC improved) in artificially demineralized monkey's teeth after three days [14]. Fluoride-releasing materials show cariostatic properties and may affect bacterial metabolism under simulated cariogenic conditions in vitro [15].

GICs have been substantially improved over the years, especially their mechanical properties, thereby expanding indications for use. These improvements include the introduction of photopolimerizable resins (light-cured GIC), or ultrafine, highly reactive glass particles, dispersed within the conventional glass ionomer structure and a higher molecular weight polyacrylic acid in hybrid GIC. The latter has led to the recently launched hybrid GIC, Equia Forte, currently the only material in this 'class' of GICs.

It has been widely accepted that during the setting action of GICs a variety of ionic constituents is released from the glass phase, including fluoride. Fluoride is released in short-term by rapid dissolution from the outer surface of the set material into solution. Sustained ion release is the consequence of ion diffusion through the bulk cement. Despite the latest improvements, it is imperative that GICs maintain abundant fluoride release in order to support their antiocariogenic potential.

The aim of the present study was to quantify and compare fluoride release from the conventional, resin- 
modified and the new glass hybrid GICs into deionized water 1, 6, $24 \mathrm{~h}, 3,7,14$ and 21 days post-setting. The null hypotheses were: (1) there is no significant difference in fluoride release from different GICs and (2) there is no significant relationship between fluoride release and sample mass/density.

\section{MATERIALS AND METHODS}

Details on the materials used in this study are given in the Table 1. All materials were used according to manufacturers' instructions. Capsules of Fuji IX, Fuji II and Equia were mixed in an auto-mixer for $10 \mathrm{~s}$. Alfagal was prepared by hand mixing 1 scoop of powder and 2 drops of liquid for $30 \mathrm{~s}$ using a plastic spatula on the paper pad. Z250 and Adper were used directly from the tube or bottle, respectively.

Standardized plastic molds, $5 \mathrm{~mm}$ in diameter and 2 $\mathrm{mm}$ deep, were placed on a Mylar strip and a glass pad, filled with GIC, composite or adhesive, covered with another strip, and pressed with a glass slide to extrude excess material and form smooth surfaces. Five samples were prepared per group, except the adhesive control group (Adper) with one prepared sample to avoid wasting material. Alfagal and Equia were allowed to set for $6 \mathrm{~min}$ and $2 \mathrm{~min} 30 \mathrm{~s}$, respectively. Fuji II, Z250 and Adper were light-cured through the Mylar strip and $1 \mathrm{~mm}$ thick glass slide using a conventional LED light-curing unit (LEDition, Ivoclar Vivadent, Schaan, Liechtenstein) operating at intensity of $800 \mathrm{~mW} / \mathrm{cm}^{2}$. Adper and Z250 were lightcured for $40 \mathrm{~s}$, and Fuji II for $20 \mathrm{~s}$ each from the top and bottom side. Each sample was weighed on an analytical balance with an accuracy of $0.1 \mathrm{mg}$ (ACCULAB ALC110.4, Sartorius group, Goettingen, Germany).

All samples were stored dry for $24 \mathrm{~h}$ at $37^{\circ} \mathrm{C}$. Following storage, each sample was immersed in $5 \mathrm{~mL}$ of deionised water in a sterile glass vial and kept at $37^{\circ} \mathrm{C}$. Fluoride concentrations were measured after $1 \mathrm{~h}, 6 \mathrm{~h}, 24 \mathrm{~h}, 3,7,14$ and 21 days using a F-selective electrode (Cole-Parmer, Bunker CT, Vernon Hills, Illinois) and an ion meter (Oakton pH/Ion 700 Bench Meter, Cole-Parmer, Bunker CT, Vernon Hills, Illinois). The electrode was first calibrated using $0.1,1$ and $10 \mathrm{ppm}$ F. Ionic Strength Adjuster solution $(0.5 \mathrm{~mL})$ was added to all tested solutions just before measuring. Between measurements the electrode was rinsed with deionized water.

Statistical analysis was performed in Minitab 16 (Minitab Inc., State College, PA, USA). The data were analyzed using one-way ANOVA with Tukey's post-hoc test for multiple comparisons at the level of significance alpha $=0.05$. Regression analysis and Pearson correlation were performed to determine the relationship between fluoride release and sample mass/density.

Table 1. Materials used in the study

Tabela 1. Materijali korišćeni u ovom istraživanju

\begin{tabular}{|c|c|c|c|}
\hline \multirow{2}{*}{\begin{tabular}{|l|} 
Material / Materijal \\
(Code / Oznaka)
\end{tabular}} & Type / Tip & \multirow{2}{*}{$\begin{array}{l}\text { Indications for use / Indikacije za } \\
\text { upotrebu }\end{array}$} & \multirow[t]{2}{*}{ Composition / Sastav } \\
\hline & Manufacturer / Proizvođač & & \\
\hline \multirow[t]{2}{*}{$\begin{array}{l}\text { ALFAGAL }{ }^{\circledR} \text { bejz } \\
\text { (Alfagal) }\end{array}$} & $\begin{array}{l}\text { Conventional glass ionomer cement / } \\
\text { Konvencionalni GJC }\end{array}$ & \multirow{2}{*}{$\begin{array}{l}\text { Base material under composite or } \\
\text { amalgam restorations } \\
\text { For cementation of prosthodontic } \\
\text { restorations and orthodontic rings } \\
\text { For atraumatic restorative treatment / } \\
\text { Baza ispod kompozitnih ili amalgamskih } \\
\text { ispuna, cementiranje protetskih } \\
\text { nadoknada i ortodontskih bravica, } \\
\text { atraumatski restaurativni tretman }\end{array}$} & \multirow{2}{*}{$\begin{array}{l}\text { Liquid / Tečnost: } 55 \% \text { water solution of } \\
\text { acrylic and itaconic acidcopolymers } \\
\text { Powder / Prah: calcium-aluminium- } \\
\text { barium-fluoro-silicate glass }\end{array}$} \\
\hline & Galenika a.d. Belgrade, Serbia & & \\
\hline \multirow{2}{*}{$\begin{array}{l}\text { GC Fuji IX GP } \\
\text { CAPSULE } \\
\text { (Fuji IX) }\end{array}$} & $\begin{array}{l}\text { Conventional reinforced glass ionomer } \\
\text { cement / Konvencionalni ojačani GJC }\end{array}$ & \multirow{2}{*}{$\begin{array}{l}\text { Final restorations (non-stress areas), } \\
\text { Intermediate Restorative (IRM), core } \\
\text { material and long-term, temporary } \\
\text { restorations / Definitivni ispuni (zone van } \\
\text { opterećenja), privremeni ispuni, dentinski } \\
\text { zamenik }\end{array}$} & \multirow{2}{*}{$\begin{array}{l}\text { Liquid / Tečnost: Polyacrylic acid, water, } \\
\text { polybasic carboxylic acid } \\
\text { Powder / Prah: Aluminofluorosilicate glass } \\
\text { polyacrylic acid powder }\end{array}$} \\
\hline & GC Corporation, Tokyo, Japan & & \\
\hline \multirow[t]{2}{*}{$\begin{array}{l}\text { GC Fuji II LC } \\
\text { (Fuji II) }\end{array}$} & $\begin{array}{l}\text { Light-cured resin-modified glass ionomer } \\
\text { cement / Svetlosno-polimerizujući } \\
\text { smolom modifikovani GJC }\end{array}$ & \multirow{2}{*}{$\begin{array}{l}\text { Class III and V Restorations, cervical } \\
\text { erosions/abfraction lesions and root } \\
\text { surface caries liner/base / Ispuni III i V } \\
\text { klase, cervikalne erozije/abfrakcije i karijes } \\
\text { korena, lajner/baza }\end{array}$} & \multirow{2}{*}{$\begin{array}{l}\text { Liquid / Tečnost: water, polyacrilic acid, } \\
\text { HEMA } \\
\text { Powder / Prah: fluoroaluminosilicate glass, } \\
\text { polyacrilic acid }\end{array}$} \\
\hline & GC Corporation, Tokyo, Japan & & \\
\hline \multirow[t]{2}{*}{$\begin{array}{l}\text { EQUIA }^{\oplus} \text { Forte } \\
\text { (Equia) }\end{array}$} & $\begin{array}{l}\text { Conventional hybrid glass-ionomer } \\
\text { cement / Konvencionalni hibridni GJC }\end{array}$ & \multirow{2}{*}{$\begin{array}{l}\text { Bulk fill glass hybrid restorative for Class } \\
\text { I, II and V restorations / „Bulk fill“ staklo- } \\
\text { hibridni materijal za ispune I, II i V klase }\end{array}$} & \multirow{2}{*}{$\begin{array}{l}\text { Liquid / Tečnost: water, polybasic } \\
\text { carboxylic acid, polyacrylic acid } \\
\text { Powder / Prah: fluoro-alumino-silicate } \\
\text { glass, iron(III)-oxide }\end{array}$} \\
\hline & GC Corporation, Tokyo, Japan & & \\
\hline \multirow{2}{*}{\begin{tabular}{|l|} 
FiltekTM Z250 \\
Universal \\
Restorative \\
$($ Z250) \\
\end{tabular}} & $\begin{array}{l}\text { Microhybrid composite / Mikrohibridni } \\
\text { kompozit }\end{array}$ & \multirow[t]{2}{*}{$\begin{array}{l}\text { All classes of restorations / Ispuni svih } \\
\text { klasa }\end{array}$} & \multirow{2}{*}{$\begin{array}{l}\text { BisEMA6, UDMA, BisGMA, TEGDMA, } \\
\text { silane-treated ceramic (75-85 wt\%), } \\
\text { benzotriazol, EDMAB }\end{array}$} \\
\hline & 3M ESPE, St. Paul, MN, USA & & \\
\hline \multirow[t]{2}{*}{$\begin{array}{l}\text { Adper Single Bond } \\
\text { (Adper) }\end{array}$} & $\begin{array}{l}\text { One-step self-etch adhesive system / } \\
\text { Jednofazni samonagrizajući adhezivni } \\
\text { sistem }\end{array}$ & \multirow[t]{2}{*}{$\begin{array}{l}\text { Adhesive for composites / Adheziv za } \\
\text { kompozite }\end{array}$} & \multirow[t]{2}{*}{$\begin{array}{l}\text { Bis-GMA, HEMA, dimethacrylates, } \\
\text { polyalkenoic acid copolymer, initiators, } \\
\text { water and ethanol }\end{array}$} \\
\hline & 3M ESPE, St. Paul, MN, USA & & \\
\hline
\end{tabular}

HEMA - 2-hydroxyethyl methacrylate; Bis-EMA - ethoxylated bisphenol A glycol dimethacrylate; UDMA - urethane dimethacrylate; Bis-GMA - bisphenol A diglycidyl ether dimethacrylate; TEGDMA - triethylene glycol dimethacrylate; EDMAB - ethyl-4-dimethylamino benzoate 


\section{RESULTS}

Aside from the control composite Z250, the mass and density of GIC samples varied significantly, with the conventional GIC Alfagal showing lower mass and density than other tested GICs $(\mathrm{p}<0.001)$ (Table 2).

Table 2. Mass and density of the tested materials per sample. Mean (standard deviation)

Tabela 2. Masa i gustina ispitivanih materijala po uzorku. Srednja vrednost (standardna devijacija)

\begin{tabular}{|c|c|c|}
\hline $\begin{array}{c}\text { Material } \\
\text { / Materijal }\end{array}$ & $\begin{array}{c}\text { Mass / } \\
\text { Masa }(\mathbf{m g})\end{array}$ & $\begin{array}{c}\text { Density / Gustina } \\
\left(\mathbf{m g} / \mathbf{m m}^{3}\right)\end{array}$ \\
\hline Z250 & $123.4(4.9)^{\mathrm{A}}$ & $3.14(0.13)^{\mathrm{A}}$ \\
\hline Fuji II & $117.2(3.2)^{\mathrm{AB}}$ & $2.98(0.08)^{\mathrm{AB}}$ \\
\hline Fuji IX & $113.0(1.7)^{\mathrm{BC}}$ & $2.88(0.04)^{\mathrm{BC}}$ \\
\hline Equia & $109.1(2.8)^{\mathrm{C}}$ & $2.78(0.07)^{\mathrm{C}}$ \\
\hline Alfagal & $94.7(3.2)^{\mathrm{D}}$ & $2.41(0.08)^{\mathrm{D}}$ \\
\hline
\end{tabular}

In each column, the same upper-case letters indicate no statistically significant difference between groups $(p>0.05)$.

$\mathrm{U}$ svakoj koloni ista velika slova ukazuju da nema statistički značajne razlike između grupa $(p>0,05)$

Fluoride release varied in concentration between materials and time periods (Figure 1). All GICs had the highest fluoride release during the first $24 \mathrm{~h}$ post-setting. Relatively high fluoride release occurred from GICs except Fuji II over the next $48 \mathrm{~h}$ (the first 3 days in total) as indicated by steep slopes in Figure 1. Further release was notable until the end of the experiment (21 days) with base/liner GIC Alfagal showing the highest fluoride release in all tested times (more than double the values of other materials) $(p<0.05)$. Equia released more fluoride than Fuji IX and Fuji II with Fuji II releasing the least fluoride concentration of the tested GICs $(\mathrm{p}<0.05)$. Fluoride release in negative control groups, both composite Z250 and Adper adhesive, was 10 or more times lower compared to GICs (11.46 \pm 2.45 and $14.81 \mathrm{ppm}$ per gram composite and adhesive, respectively, over 21 days).

Regression and Pearson correlation analysis showed significant inverse relationship between fluoride release $(\mathrm{F})$ and sample mass and density $(\mathrm{p}<0.001)$ (Figure 2). The regression equations may be expressed as Equations 1 and 2 :

$$
\begin{aligned}
& F=132.00-1020.43 \times \text { Mass } \\
& F=132.00-40.072 \times \text { Density }
\end{aligned}
$$

Equation 1. Equation 2.

$$
\text { with R-sq }=86.52 \% \text { and R-sq(adj. })=85.77 \%
$$

Pearson correlation coefficient $\mathrm{r}=-0.930$ and $\mathrm{p}<0.001$ indicate strong negative correlation between fluoride release and mass/density i.e. higher fluoride release occurred from lower density GICs.

\section{DISCUSSION}

Both null hypotheses were rejected as the results confirmed significant differences in fluoride release between

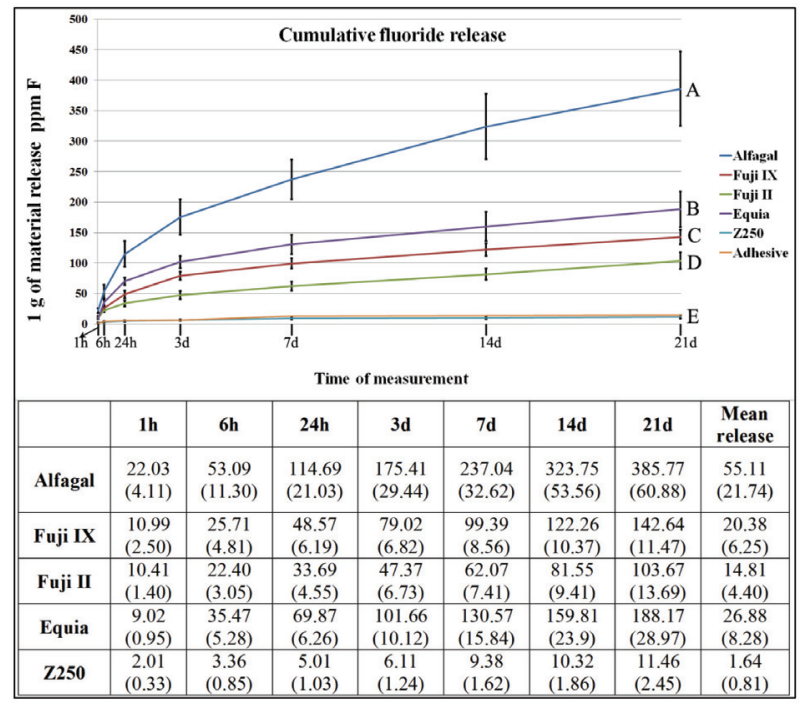

Figure 1. Fluoride release from the tested materials in different time periods. Cumulative fluoride release normalized per $1 \mathrm{~g}$ of material over the period of 21 days. For clarity, mean (standard deviation) values in ppm are presented in the accompanying table. "Mean release" indicates the amount of fluoride released between two test measurements i.e. per test period.

Grafikon 1. Otpuštanje fluorida iz ispitivanih materijala u različitim periodima. Kumulativno oslobađanje fluorida normalizovano na 1 g materijala tokom perioda od 21 dana. Zbog jasnog prikazivanja, srednja vrednost (standardna devijacija) u ppm je prikazana su u pratećoj tabeli. „Srednja vrednost oslobađanja" predstavlja količinu oslobođenog fluorida između dva merenja tj. testirang perioda.

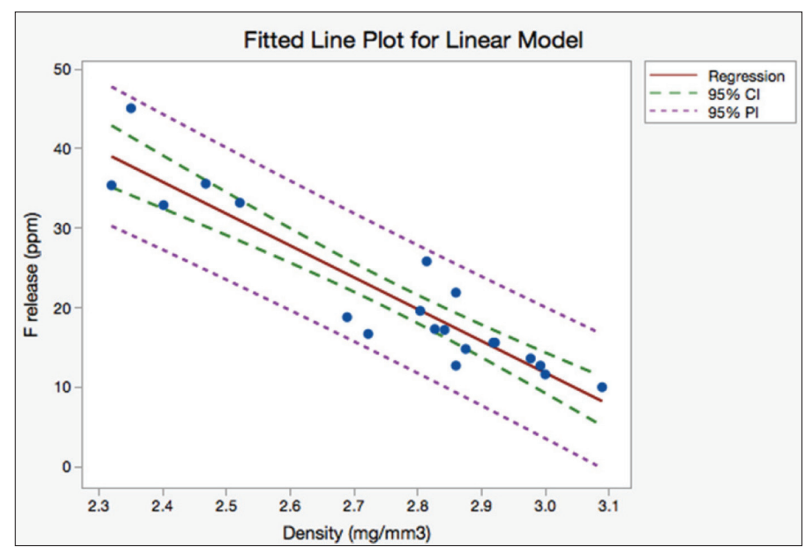

Figure 2. Regression analysis for 'F release' versus 'Mass' or 'Density' of the tested GICs. The fitted line plot for a linear model shows points adequately covering the entire range of mass/density values without any outliers or curvature in the data.

$\mathrm{Cl}$ - confidence interval; $\mathrm{PI}$ - prediction interval

Grafikon 2. Regresiona analiza za F otpuštanje nasuprot masi ili gustini ispitivanih GJC. Linearni model pokazuje tačke koje adekvatno pokrivaju čitav raspon vrednosti mase/gustine bez značajnih odstupanja u podacima.

$\mathrm{Cl}$ - interval pouzdanosti; PI - predikcioni interval

GICs as well as an inverse relationship between fluoride release and sample mass and density.

In the present study, a range of GICs with different composition was tested, from the 'classical' GIC formulated Alfagal to reinforced conventional Fuji IX, resin-modified and light-curable Fuji II to the latest glass hybrid Equia. This choice was made to cover a wide range of different GIC compositions so as to ascertain a range of potential fluoride concentrations released over a period of 21 days. 
There is a lack of standardization vis-à-vis sample size, shape, the type and quantity of immersion media as well as data presentation in the current literature. Data comparison is often difficult due to these differences. The present results are expressed as the amount of fluoride released from 1 gram of material. Deionized water was used as the immersion medium as it is most often used in other studies and has been shown to facilitate more fluoride release than artificial saliva [16].

Short- and long- term fluoride release from restorative materials is related to their matrices, setting mechanisms and fluoride content and as well as environmental conditions [15]. The present results showed the highest fluoride release from the conventional GIC Alfagal. Alfagal has the most 'classical' GIC composition of all tested GICs, based on a water solution of acrylic and itaconic acid copolymers. It is of lower density (lower viscosity) than other tested GICs and is specifically indicated for use as a liner/ base under direct and indirect restorations. Alfagal is not indicated as a filling (restorative) material, not even in non-load-bearing areas, in contrast to other tested GICs. It is well known that early, conventional GICs exhibit inferior mechanical properties than other filling materials and profound sensitivity to water imbalance, especially during the first $24 \mathrm{~h} \mathrm{[17].} \mathrm{Resin} \mathrm{modification} \mathrm{of} \mathrm{the} \mathrm{con-}$ ventional formula led to somewhat improved mechanical properties but still below those of resin-based composites [18]. Also, GICs with higher powder-to-liquid ratio exhibit better mechanical properties [19]. Higher water uptake and solubility as well as less complicated internal structure compared to GICs containing high molecular polyacrylic and polybasic carboxylic acid and/or resin monomers may have led to more pronounced fluoride release from Alfagal than other tested GICs.

Equia had higher fluoride release compared to Fuji IX and Fuji II, but the difference was not statistically significant between Equia and Fuji IX, probably due to relatively high SD values. However, the results are indicative of a tendency of higher fluoride release from Equia than Fuji IX. These two GICs share a similar composition, and Equia is considered a successor of Fuji IX. Higher fluoride content, slightly lower density or other compositional modification undisclosed by the manufacturer could be the reason(s) for somewhat higher fluoride release from Equia than Fuji IX. In clinical practice it is recommended to cover the surface of Equia restorations with Equia Forte Coat, a light-curable resin-based liquid. This coat would probably act as a semipermeable membrane, allowing partial fluoride release into the oral environment. However, low wear resistance of unfilled or very low filled resin liquid indicates that protective coat would be worn during function leaving Equia exposed for unrestricted fluoride release. As the longevity of the coat layer in clinical conditions is unpredictable and individual, the present study design without any protective layer allowed measuring maximum fluoride release for the given sample size and shape.

Previous studies reported different findings related to fluoride release from resin-modified and conventional GICs. Several studies showed no significant difference in fluoride release between light-cured and conventional GICs $[20,21,22]$. The present study detected less fluoride release from light-cured Fuji II compared to other tested GICs. Fluoride release from resin-modified GICs could be hampered by the polymer network intertwined with polyalkeenoate chains.

Following the highest fluoride release during the first $24 \mathrm{~h}$ post-setting, fluoride release from each material decreased sharply over the first week and continued to decrease steadily over the 3 weeks period which is in agreement with other studies reporting the maximum release during the first 24$48 \mathrm{~h}$ [23-27]. In all GICs a tendency for fluoride release was observable based on the increasing slope in Figure 1. This indicated that new formulations of GICs also act as a pool of fluoride with potential continuous release over a long time, especially in environment with acidic $\mathrm{pH}$. Earlier studies have shown a steady fluoride release over the period of 2 years from conventional GICs [28].

Continuous fluoride release was also detected in a rare in vivo study by Koch et al. [29] who showed that fluoride concentration in saliva immediately after placement of GIC restorations increased from 0.04 ppm to $0.8-1.2$ ppm, but slowly decreased about $35 \%$ after 3 weeks and additional $30 \%$ after 6 weeks.

Although clinical importance of fluoride as an anticariogenic agent is nowadays generally accepted, the evidence to corroborate this statement comes from in vitro and in situ studies. Randomized clinical trials offer inconclusive evidence of greater caries protection by GICs [30]. Ex vivo studies showed the potential of fluoride ions to migrate from GIC restorations into the surrounding enamel and dentin of primary molars $[31,32]$. Also, GICs were shown to inhibit secondary caries formation in vitro in artificial biofilm models $[33,34]$. Until clinical evidence becomes definitive regarding the anticariogenic efficiency of fluoride-containing materials, primarily GICs, it is important that new and improved formulations of these materials maintain high levels of fluoride release.

\section{CONCLUSION}

Conventional, glass hybrid and resin-modified GICs showed continuous release of fluoride ions over 21 days after setting. Concentrations of released fluoride differed and were affected by material composition and density. The addition of resin into GIC formulation decreased its ability to release fluoride. Higher viscosity GICs could be also linked to lower fluoride release. Of the three GICs indicated for use as restorative materials, Fuji II LC, Fuji IX and Equia Forte, the highest fluoride release occurred from Equia Forte.

\section{ACKNOWLEDGEMENT}

This study was supported by Research grants ON172007 from the Ministry of Education, Science and Technological Development, Republic of Serbia. 


\section{REFERENCES}

1. Rho YJ, Namgung C, Jin BH, Lim BS, Cho BH. Longevity of direct restorations in stress-bearing posterior cavities: a retrospective study. Oper Dent. 2013; 38:572-82. [DOI: 10.2341/12-432-c] [PMID: 23550914]

2. Demarco FF, Correa MB, Cenci MS, Moraes RR, Opdam NJ. Longevity of posterior composite restorations: not only a matter of materials. Dent Mater. 2012; 28:87-101. [DOI: 10.1016/j.dental.2011.09.003] [PMID: 22192253]

3. Kopperud SE, Tveit AB, Gaarden T, Sandvik L, Espelid I. Longevity of posterior dental restorations and reasons for failure. Eur J Oral Sci. 2012; 120:539-48. [DOI: 10.1111/eos.12004] [PMID: 23167471]

4. Nedeljkovic I, De Munck J, Slomka V, Van Meerbeek B, Teughels W, Van Landuyt KL. Lack of Buffering by Composites Promotes Shift to More Cariogenic Bacteria. J Dent Res. 2016; 95:875-81. [DOI: 10.1177/0022034516647677] [PMID: 27713453]

5. Forss H, Seppa L. Prevention of enamel demineralization adjacent to glass ionomer filling materials. Scand J Dent Res. 1990; 98:173-8. [DOl: 10.1111/j.1600-0722.1990.tb00957.x] [PMID: 2111576]

6. Skartveit L, Tveit AB, Totdal B, Ovrebo R, Raadal M. In vivo fluoride uptake in enamel and dentin from fluoride-containing materials. ASDC J Dent Child. 1990; 57:97-100. [PMID: 2319061]

7. Dionysopoulos P, Kotsanos N, Papadogiannis Y, Konstantinidis A. Artificial secondary caries around two new $F$-containing restoratives. Oper Dent. 1998; 23:81-6. [PMID: 9573793]

8. Donly KJ. Enamel and dentin demineralization inhibition of fluoridereleasing materials. Am J Dent. 1994; 7:275-8. [PMID: 7986452]

9. Mohammed NR, Lynch RJ, Anderson P. Effects of fluoride concentration on enamel demineralization kinetics in vitro. I Dent. 2014; 42:613-8. [DOI: 10.1016/j.jdent.2013.12.005] [PMID: 24373853]

10. Almeida Ayres AP, Tabchoury CP, Bittencourt Berger S, Yamauti M, Bovi Ambrosano GM, Giannini M. Effect of Fluoride-containing Restorative Materials on Dentin Adhesion and Demineralization of Hard Tissues Adjacent to Restorations. J Adhes Dent. 2015; 17:337-45. [DOI: 10.3290/i.jad.a34555] [PMID: 26258176]

11. Nantanee R, Santiwong B, Trairatvorakul C, Hamba H, Tagami J. Silver diamine fluoride and glass ionomer differentially remineralize early caries lesions, in situ. Clin Oral Investig. 2016; 20:1151-7. [DOI: 10.1007/s00784-015-1603-4] [PMID: 26395352]

12. Thepyou R, Chanmitkul W, Thanatvarakorn O, Hamba H, ChobIsara W, Trairatvorakul C, et al. Casein phosphopeptide-amorphous calcium phosphate and glass ionomer show distinct effects in the remineralization of proximal artificial caries lesion in situ. Dent Mater J. 2013; 32:648-53. [DOI: 10.4012/dmj.2012-253] [PMID: 23903649]

13. Marquis RE. Antimicrobial actions of fluoride for oral bacteria. Can J Microbiol. 1995; 41:955-64. [PMID: 7497353]

14. Kitasako Y, Nakajima M, Foxton RM, Aoki K, Pereira PN, Tagami J. Physiological remineralization of artificially demineralized dentin beneath glass ionomer cements with and without bacterial contamination in vivo. Oper Dent. 2003; 28(3):274-80. [PMID: 12760699]

15. Wiegand A, Buchalla W, Attin T. Review on fluoride-releasing restorative materials--fluoride release and uptake characteristics, antibacterial activity and influence on caries formation. Dent Mater. 2007; 23:343-62. [DOI: 10.1016/j.dental.2006.01.022]

16. el Mallakh BF, Sarkar NK. Fluoride release from glass-ionomer cements in de-ionized water and artificial saliva. Dent Mater. 1990; 6:118-22. [DOI: 10.1016/S0109-5641(05)80041-7]

17. Walls AW. Glass polyalkenoate (glass-ionomer) cements: a review. J Dent. 1986; 14:231-46. [DOl: 10.1016/0300-5712(86)90030-8]
18. McCabe JF. Resin-modified glass-ionomers. Biomaterials. 1998; 19:521-7. [DOI: 10.1016/S0142-9612(98)00132-x]

19. Sidhu SK, Nicholson JW. A Review of Glass-lonomer Cements for Clinical Dentistry. J Funct Biomater. 2016; 7. [DOI: 10.3390/jfb7030016] [PMID: 27367737]

20. Momoi Y, McCabe JF. Fluoride release from light-activated glass ionomer restorative cements. Dent Mater. 1993; 9:151-4. [DOI: 10.1016/0109-5641(93)90112-4] [PMID: 8056168]

21. Tam LE, Chan GP, Yim D. In vitro caries inhibition effects by conventional and resin-modified glass-ionomer restorations. Oper Dent. 1997; 22(1):4-14. [PMID: 9227122]

22. Forsten L. Fluoride release and uptake by glass-ionomers and related materials and its clinical effect. Biomaterials. 1998; 19:503-8. [DOl: 10.1016/S0142-9612(97)00130-0]

23. Creanor SL, Carruthers LM, Saunders WP, Strang R, Foye RH. Fluoride uptake and release characteristics of glass ionomer cements. Caries Res. 1994; 28:322-8. [DOI: 10.1159/000261996] [PMID: 8001053]

24. Bell A, Creanor SL, Foye RH, Saunders WP. The effect of saliva on fluoride release by a glass-ionomer filling material. J Oral Rehabil. 1999; 26:407-12. [DOI: 10.1046/j.1365-2842.1999.00389.x] [PMID: 10373088]

25. Attar N, Onen A. Fluoride release and uptake characteristics of aesthetic restorative materials. J Oral Rehabil. 2002; 29:791-8. [DOI: 10.1046/j.1365-2842.2002.00902.x]

26. Diaz-Arnold AM, Holmes DC, Wistrom DW, Swift E), Jr. Short-term fluoride release/uptake of glass ionomer restoratives. Dent Mater. 1995; 11:96-101. [DOI: 10.1016/0109-5641(95)80041-7]

27. Karantakis P, Helvatjoglou-Antoniades M, Theodoridou-Pahini S, Papadogiannis Y. Fluoride release from three glass ionomers, a compomer, and a composite resin in water, artificial saliva, and lactic acid. Oper Dent. 2000; 25:20-5.

28. Forsten L. Short- and long-term fluoride release from glass ionomers and other fluoride-containing filling materials in vitro. Scand J Dent Res. 1990; 98:179-85.

29. Koch G, Hatibovic-Kofman S. Glass ionomer cements as a fluoride release system in vivo. Swed Dent J. 1990; 14:267-73. [PMID: 2096475]

30. Cury JA, de Oliveira BH, dos Santos AP, Tenuta LM. Are fluoride releasing dental materials clinically effective on caries control? Dent Mater. 2016; 32(3):323-33. [DOI: 10.1016/j.dental.2015.12.002] [PMID: 26777115]

31. Bezerra AC, Novaes RC, Faber J, Frencken JE, Leal SC. Ion concentration adjacent to glass-ionomer restorations in primary molars. Dent Mater. 2012; 28:e259-63. [DOI: 10.1016/j.dental.2012.08.014] [PMID: 22999372]

32. Mass E, Hassan A, Zilberman U. Long-term in-vivo effect of various restorative materials on enamel and dentin of primary molars. Quintessence Int. 2017; 48(8):633-8. [DOI: 10.3290/j.qi.a38557] [PMID: 28681046]

33. Amend S, Frankenberger R, Lucker S, Domann E, Kramer N. Secondary caries formation with a two-species biofilm artificial mouth. Dent Mater. 2018; 34(5):786-96. [DOl: 10.1016/j.dental.2018.02.002] [PMID: 29544984]

34. Kramer N, Schmidt M, Lucker S, Domann E, Frankenberger R. Glass ionomer cement inhibits secondary caries in an in vitro biofilm model. Clin Oral Investig. 2018; 2:1019-31. [DOI: 10.1007/s00784-017-2184-1] [PMID: 28741172]

Received: 17.09.2018 • Accepted: 20.11.2018 


\title{
Otpuštanje fluorida iz konvencionalnih, smolom modifikovanih i hibridnih glas-jonomer cemenata
}

\author{
Maja Ležaja Zebić, Nikola Jakovljević, Vesna Miletić \\ Univerzitet u Beogradu, Stomatološki fakultet, Klinika za bolesti zuba i endodonciju, Beograd, Srbija
}

\begin{abstract}
KRATAK SADRŽAJ
Uvod Cilj ovog istraživanja je bio da se kvantifikuje i uporedi otpuštanje fluorida iz četiri glas-jonomer cementa (GJC).

Materijal i metode Napravljeni su standardizovani diskovi $(5 \times 2 \mathrm{~mm}$; $=5 /$ grupa) od sledećih G)C: konvencionalnih (Fuji IX, GC Corp., Japan), smolom modifikovani (Fuji II LC, GC), hibridni GJC (Equia Forte, GC) i konvencionalni GJC lajner/baza (Alfagal, Galenika, Srbija). Ispitivano je otpuštanje fluorida tokom 21 dana tako što je svaki uzorak potapan u $5 \mathrm{ml}$ sveže destilovane vode posle svakog mernog intervala. Univerzalni mikrohibridni kompozit (Filtek Z250, 3M EPSE, USA) i adheziv (Adper Single Bond, 3M ESPE) korišćeni su kao negativne kontrole. Otpuštanje fluorida je očitavano pomoću fluor-selektivne elektrode (Cole-Parmer, USA) i jon-metra (Oakton 700, Cole-Parmer, USA). Rezultati su statistički obrađeni ANOVA testom, regresionim i korelacionim analizama sa $\alpha=0,05$. Rezultati Ukupno otpuštanje fluorida je bilo najveće iz Alfagala (386 $\pm 61 \mathrm{ppm} / \mathrm{g}$ ), značajno manje iz Equia Forte (188 $\pm 29 \mathrm{ppm} / \mathrm{g}$ ), Fuji IX (143 \pm 11 ppm/g), a najmanje iz Fuji II LC $(104 \pm 14 \mathrm{ppm} / \mathrm{g})(\mathrm{p}<0,05)$. Svi GJC pokazali su najveće otpuštanje fluorida u toku prva $24 \mathrm{~h}$ po vezivanju. Posle tri dana otpuštanje fluorida je postajalo sporije dostižući plato za sva četiri materijala. Regresiona i Pirsonova korelaciona analiza pokazale su značajan obrnut odnos između otpuštanja fluorida i mase i gustine uzoraka $(p<0,001)$. Zaključak Od GJC indikovanih za ispune, Equia Forte je otpustila najveću koncentraciju fluorida. Otpuštanje fluorida zavisi od materijala i njegove gustine, pri čemu GJC manje gustine otpuštaju više fluorida.

Ključne reči: fluoridi; glas-jonomer cement; hibridno staklo; smolom modifikovani glas-jonomer
\end{abstract}

\section{UVOD}

Jedan od glavnih uzroka neuspeha restauracije jeste sekundarni karijes $[1,2,3]$, koji dovodi do daljeg gubitka zubnih tkiva, oslabljene strukture zuba, pa čak i gubitka zuba. Klinički je značajan svaki mehanizam koji umanjuje produkciju kiselina od strane bakterija, povećava otpornost na demineralizaciju ili potpomaže proces remineralizacije. Skorašnja studija je pokazala da najčešće korišćeni restaurativni materijali, kompoziti, ne poseduju puferski potencijal, te su stoga podložniji nastanku sekundarnog karijesa oko ruba ispuna [4].

Fluoridi otpušteni iz fluoridima bogatih materijala imaju sposobnost da stupe u hemijsku interakciju sa hidroksiapatitom iz gleđi i dentina u neposrednoj blizini ispuna, što za posledicu ima nastanak fluorapatita $[5,6]$, koji povećava otpornost na demineralizaciju i preventivno deluje na nastanak sekundarnog karijesa $[7,8]$. Fluoridi koji su otpušteni iz materijala koji sadrže fluoride, kao što su glas-jonomer cementi (GJC), mogu poboljšati otpornost na demineralizaciju $[9,10]$, potpomoći proces remineralizacije $[11,12]$ ili čak direktno uticati na kariogene bakterije inhibiranjem njihovih metaboličkih enzima [13]. Registrovano je otpuštanje fluorida iz dubljih partija GJC ispuna (Fuji IX i unapređeni Fuji II LC) u dentinu veštački demineralizovanih zuba majmuna posle tri dana od restauracije [14]. Materijali koji otpuštaju fluoride pokazuju kariostatske osobine i mogu uticati na bakterijski metabolizam u simuliranim kariogenim uslovima in vitro [15].

GJC su poslednjih godina značajno unapređeni, pogotovo na polju mehaničkih karakteristika, što je dovelo do širenja indikacija za njihovo korišćenje. Ova unapređenja su dobijena uvođenjem svetlosno polimerizujućih smola (svetlosno polimerizujući GJC) ili dodavanjem ultrafinih, visoko reaktivnih staklenih punilaca raspršenih unutar konvencionalne glas-jonomerne strukture, kao i primenom poliakrilne kiseline veće molekulske mase u hibridnim GJC. To je vodilo i ka nedavnoj pojavi hibridnog GJC, Equia Forte, trenutno jedinog materijala u ovoj „klasi“ GJC.
Široko je prihvaćeno da tokom vezivanja GJC otpuštaju brojne jonske konstituente iz staklene faze, uključujući i fluoride. Fluoridi se prvobitno naglo otpuštaju brzim rastvaranjem spoljašnje površine postavljenog materijala u rastvor. Kontinuirano otpuštanje jona je posledica difuzije samih jona kroz cement. Uprkos skorašnjim unapređenjima, imperativ je da GJC zadrže obilno otpuštanje fluorida, kako bi ostvarili svoj antikariogeni potencijal.

Cilj ove studije je bio da se kvantifikuje i uporedi otpuštanje fluorida iz konvencionalnih, smolom modifikovanih GJC i novog hibridnog GJC u destilovanoj vodi nakon 1, 6, 24 h i nakon $3,7,14,21$ dana od momenta vezivanja materijala. Nulte hipoteze su glasile: (1) nema značajne razlike u otpuštanju fluorida iz različitih vrsta GJC i (2) ne postoji značajna veza između otpuštanja fluorida i mase/gustine samih uzoraka.

\section{MATERIJAL I METOD}

Detaljni opisi materijala koji su korišćeni u ovoj studiji dati su u Tabeli 1. Svi materijali korišćeni su po uputstvu proizvođača. Kapsule Fuji IX, Fuji II i Equia Forte su mešane u auto-mikseru 10 s. Alfagal je zamešan ručnim mešanjem jedne kašičice praha i dve kapi tečnosti plastičnom špatulom na papirnoj podlozi u trajanju od 30 s. Kompozit Z250 i Adper su korišćeni direktno iz tube ili bočice.

Standardni plastični kalupi visine $2 \mathrm{~mm}$ i širine $5 \mathrm{~mm}$ su postavljeni na celuloidnu traku i staklenu pločicu, potom su napunjeni GJC, kompozitom ili adhezivom. Tako napunjeni kalupi su zatim prekriveni drugom tračicom i pritisnuti drugom staklenom pločicom kako bi se eliminisao višak materijala i dobile glatke površine uzoraka. Pravljeno je po pet uzoraka u svakoj grupi, osim $\mathrm{u}$ adhezivnoj kontrolnoj grupi, gde je napravljen jedan uzorak kako bi se izbegao nepotreban gubitak materijala. Alfagal i Equia Forte su se vezivali šest min. odnosno dva min. i 30 s. Fuji II LC, Z250 i Adper su svetlosno polimerizovani kroz celuloidnu tračicu i staklenu pločicu debljine $1 \mathrm{~mm}$ po- 
moću konvencionalne LED lampe (LEDition, Ivoclar Vivadent, Schaan, Lihtenštajn) iradijanse $800 \mathrm{~mW} / \mathrm{cm}^{2}$. Adper i Z250 su prosvetljavani po $40 \mathrm{~s}$, a Fuji II LC po $20 \mathrm{~s}$ sa gornje i sa donje strane uzorka. Masa svakog uzorka je merena na analitičkoj vagi sa preciznošću od 0,1 mg (ACCULAB ALC-110.4, Sartorius group, Goettingen, Nemačka).

Svi uzorci su ostavljeni da stoje $24 \mathrm{~h}$ na temperaturi od $37^{\circ} \mathrm{C}$, posle čega je svaki uzorak potopljen u $5 \mathrm{ml}$ destilovane vode u sterilnoj staklenoj bočici i čuvan na temperaturi od $37^{\circ} \mathrm{C}$. Koncentracije fluorida merene su nakon 1 h, 6 h, 24 h, 3, 7, 14 i 21 dana pomoću fluor-selektivne elektrode (Cole-Parmer, Bunker CT, Vernon Hills, Illinois) i jon-metra (OaktonpH/Ion 700 Bench Meter, Cole-Parmer, Bunker CT, Vernon Hills, Illinois). Pre svakog merenja elektroda je kalibrisana sa rastvorima poznatih koncentracija fluorida 0,1, 1 i 10 ppm F. Rastvor Ionic Strength Adjuster $(0,5 \mathrm{ml})$ dodavan je u sve ispitivane rastvore pre merenja. Između svakog očitavanja elektroda je isprana destilovanom vodom.

Statistička analiza je urađena u statističkom programu Minitab 16 (Minitab Inc., State College, PA, USA). Podaci su analizirani jednofaktorskim ANOVA testom uz Tukey post-hoc test za multipla poređenja sa nivoom značajnosti $\alpha=0,05$. Regresiona $\mathrm{i}$ Pirsonova korelaciona analiza su primenjene kako bi se utvrdila veza između otpuštanja fluorida i mase/gustine uzoraka.

\section{REZULTATI}

Izuzev kontrolne grupe (Z250), masa i gustina GJC uzoraka je značajno varirala, pri čemu je konvencionalni GJC Alfagal pokazao manju masu i gustinu nego ostali testirani GJC ( $\mathrm{p}<$ 0,001) (Tabela 2).

Otpuštanje fluorida je variralo u koncentracijama između materijala i vremenskih intervala (Grafikon 1). Svi GJC pokazali su najveće otpuštanje fluorida u prva $24 \mathrm{~h}$ posle vezivanja. Relativno visoko otpuštanje fluorida se dešavalo i u sledećih 48 h (prva tri dana) sa izuzetkom Fuji II LC, kao što se vidi u Grafikonu 1. Dalje otpuštanje fluorida je beleženo do kraja eksperimenta (21 dan), pri čemu je Alfagal baza/lajner pokazao najveće otpuštanje fluorida u svim ispitivanim vremenskim intervalima (više nego duplo u odnosu na druge materijale) $(\mathrm{p}<0,05)$. Otpuštanje fluorida iz Equia Forte je bilo više nego iz Fuji IX i Fuji II LC, pri čemu je Fuji II LC otpustio najmanju količinu fluorida od svih ispitivanih GJC $(\mathrm{p}<0,05)$. Otpuštanje fluorida u negativnim kontrolnim grupama, kompozit Z250 i Adper adheziv, bilo je deset i više puta manje u poređenju sa kontrolama (11,46 $\pm 2,45$ i 14,81 ppm po gramu kompozita i adheziva tokom 21 dana).

Regresiona i Pirsonova korelaciona analiza su pokazale značajnu obrnutu vezu između otpuštanja fluorida (F) i mase/ gustine $(\mathrm{p}<0,001)$ (Figure 2). Regresione jednačine mogu biti predstavljene kao jednačine 1 i 2 .

$$
\begin{aligned}
& F=132,00-1020,43 \times \text { masa } \\
& F=132,00-40,072 \times \text { gustina }
\end{aligned}
$$

Jednačina 1. Jednačina 2.

$$
\text { sa } \mathrm{R} \text {-sq }=86,52 \% \text { and R-sq(adj.) }=85,77 \%
$$

Pirsonov korelacioni koeficijent $\mathrm{r}=-0,930$ i $\mathrm{p}<0,001$ ukazuje na jaku negativnu korelaciju između otpuštanja fluorida i mase/gustine. GJC manje gustine otpuštali su veću količinu fluorida.

\section{DISKUSIJA}

Obe nulte hipoteze su odbačene, jer su rezultati potvrdili značajne razlike u otpuštanju fluorida između GJC, kao i obrnutu vezu između otpuštanja fluorida i mase/gustine uzorka.

U ovoj studiji ispitano je više GJC različitog sastava, od „klasično“ formulisanog GJC, Alfagala, ojačanog konvencionalnog Fuji IX, smolom modifikovanog i svetlosno polimerizujućeg Fuji II do GJC sa hibridnim staklenim puniocima, Equia. Ovaj izbor je napravljen kako bi se pokrio širok dijapazon različitih sastava GJC i kako bi se utvrdio opseg mogućeg otpuštanja fluorida tokom ispitivanog perioda od 21 dan.

U literaturi je primetno odsustvo standardizacije u smislu veličine i oblika uzorka, tipa i količine imerzionog medijuma, kao i u prezentaciji dobijenih podataka u trenutno dostupnoj literaturi. Upoređivanje dobijenih podataka je često teško zbog ovih razlika. Zbog toga je u ovoj studiji otpuštanje fluorida normirano na jedan gram materijala. Destilovana voda je korišćena kao imerzioni medijum, po ugledu na druga istraživanja, jer je pokazano da više olakšava otpuštanje fluorida u odnosu na veštačku pljuvačku [16].

Kratkoročno i dugoročno otpuštanje fluorida iz restaurativnih materijala je u vezi sa njihovim matriksom, mehanizmima vezivanja, količinom fluorida koje poseduju, a zavisi i od uslova okoline [15]. Rezultati našeg istraživanja pokazuju najveće otpuštanje fluorida iz konvencionalnog GJC Alfagala. Alfagal ima „najklasičniji“ sastav od svih testiranih GJC. Počiva na vodenom rastvoru akrilnih i itakonskih kiselinskih kopolimera. Manje je gustine (manje viskoznosti) od ostalih ispitivanih GJC i usko je indikovan za korišćenje kao lajner/baza ispod direktnih i indirektnih ispuna. Alfagal nije indikovan za ispune, čak i u regijama koje ne trpe veliki pritisak žvakanja, za razliku od ostalih ispitivanih GJC. Dobro je poznato da su rani, konvencionalni GJC imali izrazito inferiorna mehanička svojstva u poređenju sa drugim materijalima za ispune i da su imali ozbiljnu osetliivost na disbalans vode, pogotovo $u$ toku prva $24 \mathrm{~h}$ [17]. Dodatak smole konvencionalnoj formulaciji je rezultirao donekle unapređenim mehaničkim svojstvima GJC, ali je to i dalje bilo ispod nivoa kompozita [18]. Takođe, GJC koji su u svom sastavu imali više praha nego tečnosti imali su bolja mehanička svojstva [19]. Veća asorpcija vode i rastvorljivost, jednostavnija unutrašnja struktura u poređenju sa GJC, koji u svom sastavu imaju velike molekule poliakrilne i polikarboksilne kiseline i/ili smolu, može objasniti izraženije otpuštanje fluorida iz Alfagala nego iz ostalih ispitivanih GJC.

Equia Forte je pokazala veće otpuštanje fluorida u poređenju sa Fuji IX i Fuji II LC, ali ta razlika nije bila statistički značajna između Equia Forte i Fuji IX GJC, verovatno zbog relativno visokih vrednosti standardnih devijacija. Ipak rezultati ukazuju na tendenciju većeg otpuštanja fluorida iz Equia Forte nego iz Fuji IX. Ova dva GJC imaju sličan sastav, pri čemu se Equia smatra naslednikom Fuji IX. Veći depo fluorida, neznatno manja gustina ili druga modifikacija u sastavu, koju proizvođač drži u tajnosti, može biti razlog (ili razlozi) za donekle veće otpuštanje fluorida iz Equia Forte nego iz Fuji IX. U kliničkoj praksi je preporučeno da se površina Equia zaštiti premazom Equia Forte Coat. U pitanju je svetlosno polimerizujući lak na 
bazi smole. Ovaj lak bi se verovatno ponašao kao semipermeabilna membrana, koja bi omogućila samo delimično otpuštanje fluorida u oralnu sredinu. Ipak, mala otpornost na trošenje smolastog laka koji u svom sastavu nema punioce bi značilo da bi lak mogao biti potrošen u funkciji žvakanja, što bi dovelo do direktne izloženosti Equia oralnoj sredini i nesmetanom otpuštanju fluorida iz nje. Kako je dugotrajnost premaza u kliničkim uslovima nepredvidiva i individualna, u ovoj studiji je korišćena Equa bez zaštitnog laka kako bi se omogućilo merenje mogućeg maksimalnog otpuštanja fluorida iz ispitivanog uzorka.

Ranija istraživanja su pokazala različite podatke vezane za otpuštanje fluorida iz smolom modifikovanih i konvencionalnih GJC. Nekoliko studija su pokazale da ne postoji značajna razlika u otpuštanju fluorida između konvencionalnih i smolom modifikovanih GJC $[20,21,22]$. U ovoj studiji uočeno je manje otpuštanje fluorida iz svetlosno polimerizujućeg Fuji II LC u odnosu na druge ispitivane GJC. Otpuštanje fluorida iz smolom modifikovanih GJC može biti otežano usled mreže polimera koja se prepliće sa poliakrilatnim lancima.

Posle najvećeg otpuštanja fluorida tokom prva $24 \mathrm{~h}$ od vezivanja, otpuštanje fluorida iz svakog materijala se smanjilo naglo tokom prve nedelje i nastavilo da se stalno smanjuje tokom naredne tri nedelje, što je u saglasnosti sa drugim studijama koje navode maksimalno otpuštanje fluorida tokom prvih 24-48 h [23-27]. U svim ispitivanim GJC tendencija ka otpuštanju fluorida je posmatrana prema povećanju nagiba u Grafikonu 1. Ovo ukazuje na to da nove formulacije sastava GJC takođe stvaraju rezervoar fluorida sa mogućim kontinuiranim otpuštanjem tokom dugog perioda, pogotovo u uslovima kiselog $\mathrm{pH}$. Ranija istraživanja su pokazala stalno otpuštanje fluorida tokom dve godine iz konvencionalnih GJC [28].

Kontinuirano otpuštanje fluorida je uočeno i u retkoj in vivo studiji Kocha i sar. [29], koji su pokazali da količina fluorida u salivi neposredno posle postavljanja GJC ispuna raste sa 0,04 ppm na $0,8-1,2$ ppm, ali lagano opada za oko $35 \%$ posle tri nedelje i dodatnih $30 \%$ posle šest nedelja.

Iako je klinička važnost fluorida kao antikariogenog činioca danas prihvaćena, dokazi koji potkrepljuju ovu tvrdnju dolaze iz in vitro i in situ studija. Randomizovana klinička ispitivanja nude nedovoljno dokaza o većem antikariogenom potencijalu GJC [30]. Ex vivo studije su pokazale potencijal fluoridnih jona da migriraju iz GJC ispuna u okolnu gleđ i dentin mlečnih molara [31,32]. Takođe je pokazano da GJC inhibiraju nastanak sekundarnog karijesa in vitro u veštačkim biofilm modelima $[33,34]$. U nedostatku konkluzivnih kliničkih dokaza, u smislu antikariogene efikasnosti materijala koji u svom sastavu sadrže fluor (na prvom mestu GJC), važno je da nove i unapređene formulacije ovih materijala zadrže visok nivo otpuštanja fluorida.

\section{ZAKLJUČAK}

Konvencionalni, staklohibridni i smolom modifikovani GJC su pokazali kontinuirano otpuštanje fluorida tokom 21 dana od vezivanja. Koncentracije otpuštenih fluorida variraju i zavise od sastava materijala i njegove gustine. Dodatak smole u formulaciju GJC smanjuje mogućnost otpuštanja fluorida. Viskozniji GJC mogli bi biti povezani sa slabijim otpuštanjem fluorida. Od tri GJC koji su indikovani kao materijali za ispune (Fuji II LC, Fuji IX, Equia Forte), najveće otpuštanje fluorida je pokazala Equia Forte.

\section{ZAHVALNICA}

Ovo istraživanje je podržano od strane projekta ON172007 Ministarstva prosvete, nauke i tehnološkog razvoja, Republike Srbije. 